\title{
45. PETROGRAPHY AND GEOCHEMISTRY OF ORGANIC MATTER IN CRETACEOUS SEDIMENTS FROM THE GOBAN SPUR, DEEP SEA DRILLING PROJECT LEG 80$^{1}$
}

\author{
Birgitta Hartung, Prasanta K. Mukhopadhyay, Jürgen Rullkötter, Rainer G. Schaefer, and Dietrich H. Welte, \\ Institute for Petroleum and Organic Geochemistry, Jülich, Federal Republic of Germany ${ }^{2}$
}

\begin{abstract}
Three lower Barremian to middle/upper Cenomanian samples from DSDP Hole 549 and three lower Cenomanian to lower Maestrichtian samples from DSDP Hole 550B were investigated by organic geochemical and organic petrographic methods. The samples came from wells drilled in the area of the Goban Spur in the northeastern Atlantic; they represent gray to greenish gray carbonaceous mud or siltstones from the deeper parts of the Cretaceous sequences penetrated and light-colored chalks from the shallower ones.

The total amount of organic carbon is below $1 \%$ in all samples; it is especially low in the Cenomanian to Maestrichtian chalks. Terrigenous organic matter predominates; only the Barremian sample shows a moderate number of marine phytoclasts. As indicated by several parameters, the maturity of the organic matter is low, corresponding to about $0.4 \%$ vitrinite reflectance.
\end{abstract}

\section{INTRODUCTION AND GEOLOGICAL SETTING}

Drilling at DSDP Leg 80 was devoted to investigating the complex structural evolution and environmental history of the Goban Spur in the northeastern Atlantic. Site 549 is near the Pendragon Escarpment (Fig. 1), above the seaward tip of a structural high (water depth 2535.5 $\mathrm{m})$. The chief objectives at this site were to penetrate the post-rift as well as the syn-rift sediments and to determine the age and nature of each. The sedimentary sequence is divided into 11 lithologic units, starting with Hercynian basement, overlain by lower Barremian to Miocene mudstones, siltstones, and carbonates, which are in turn overlain by Pleistocene nannofossil/foraminiferal oozes (Fig. 2). Three Lower to mid-Cretaceous samples were investigated; the oldest sediment is from the syn-rift phase, and the younger samples represent post-rift sediments: a lower Barremian sandy mudstone of Subunit 10d and a mid-Albian siltstone of Unit 6 were both deposited at high accumulation rates (60 and $67.5 \mathrm{~m} / \mathrm{m}$.y., respectively), whereas a middle to upper Cenomanian nannofossil chalk of Unit 5 accumulated at a distinctly lower rate of $3.5 \mathrm{~m} / \mathrm{m}$.y.

Site 550 is on the abyssal plain ( $4432 \mathrm{~m}$ water depth) southwest of the seaward edge of the Goban Spur (Fig. 1), above a structurally high block of oceanic basement. Drilling at this site was designed to determine the age, composition, and subsidence history of the oceanic basement. The basement is overlain by an uppermost Albian to lower Paleocene sedimentary sequence divided into six lithologic units (Fig. 2). The organic matter of three Cretaceous samples from Hole 550B was studied; the samples were a lower Cenomanian dark gray mudstone (part of a sequence of interbedded light and dark mudstones [Unit 5]), a (Coniacian?-) Santonian dark mud-

\footnotetext{
${ }^{1}$ Graciansky, P. C. de, Poag, C. W., et al., Init. Repts. DSDP, 80: Washington (U.S. Govt, Printing Office)

2 Address: Institute for Petroleum and Organic Geochemistry (ICH-5), KFA Jülich GmbH, P.O. Box 1913, D-5170 Jülich 1, Federal Republic of Germany.
}

stone (Subunit 4b), and a lower Maestrichtian light-colored nannofossil chalk (Subunit 3b).

The samples were investigated using organic geochemical and organic petrographic methods. The amount and composition of the organic matter are discussed in terms of its possible origin, the environmental conditions during its deposition, and its diagenetic alteration.

\section{EXPERIMENTAL METHODS}

For a detailed description of the experimental procedures for organic carbon determination, Rock-Eval pyrolysis, solvent extraction, liquid chromatography, capillary-column gas chromatography, and computerized gas chromatography/mass spectrometry, we refer to an earlier report (Rullkötter et al., 1981). For details of the microscopic kerogen investigation, see Mukhopadhyay et al. (1983).

\section{RESULTS AND DISCUSSION}

\section{Organic Carbon}

Table 1 shows the total organic carbon contents of the six sediment samples from DSDP Holes 549 and 550B. Only the middle Albian and lower Barremian samples from Hole 549 contain slightly more than $0.5 \%$ organic carbon, whereas the organic carbon content of the other samples is low (Samples 550B-15-3, 126-128 cm and 550B$21-5,121-126 \mathrm{~cm}$ ) to extremely low (about $0.05 \%$; Samples 549-28-1, 135-145 cm and 550B-11-2, 120-130 cm).

\section{Type and Maturity of Organic Matter}

The Rock-Eval pyrolysis data (Espitalié et al., 1977) show low hydrogen index values (11-69 mg hydrocarbons/g C $\mathrm{C}_{\text {org }}$ for all four samples investigated (the extremely organic-carbon-lean samples were not pyrolyzed), whereas the oxygen index values are high for Samples $549-45-5,120-130 \mathrm{~cm}, 550 \mathrm{~B}-15-3,126-128 \mathrm{~cm}$, and 550B$21-5,121-126 \mathrm{~cm}$ and low for Sample 549-88-2, 126-130 $\mathrm{cm}$ (Table 1). As shown in Figure 3, the kerogen is characterized as type III organic matter (terrigenous origin) in Sample $549-88-2,126-130 \mathrm{~cm}$ and as a strongly oxidized, residual type in the other three samples. 


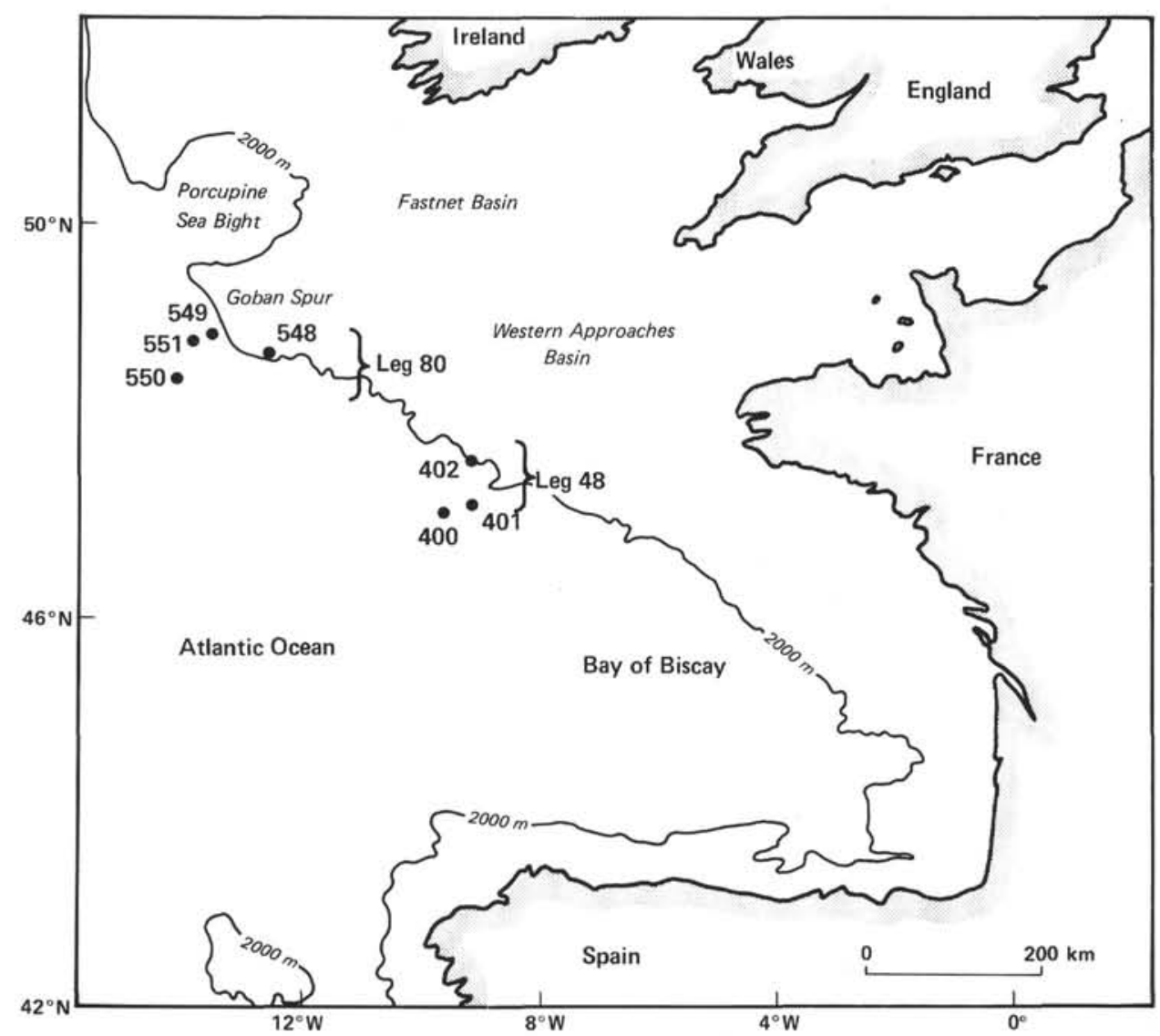

Figure 1. Locations of DSDP Sites 549 and 550 in the northeastern Atlantic Ocean (after de Graciansky et al., in press).

The results of the microscopic kerogen analyses are given in Table 2. Samples with less than $0.5 \% \mathrm{C}_{\text {org }}$ did not yield sufficient kerogen quantities during density separation, and whole-rock microscopy of these samples did not give unambiguous results. For the nomenclature of the maceral analysis, we refer to earlier reports (Rullkötter et al., 1984 and in press). Since the term "bituminite" (Teichmüller and Ottenjann, 1977) often causes confusion, we used a different terminology for the amorphous organic matter (Table 2; cf. Mukhopadhyay et al., 1983; Mukhopadhyay et al., in press; Rullkötter et al., 1984). Samples 549-45-5, 120-130 cm and 549-88-2, 126-130 $\mathrm{cm}$ show a dominance of organic matter of terrestrial origin: vitrinite, biodegraded humic matter, inertinite, and particulate liptinite B. Vitrinite is the predominant maceral. Sample $549-45-5,120-130 \mathrm{~cm}$ contains a very large amount of recycled vitrinite, with several populations at different reflectance values (one at $0.8 \%-1.0 \%$ $R_{m}$, others at $1.2-1.6 \% R_{m}$ and $1.9-2.2 \% R_{m}$ ) and much inertinite. Sample $549-88-2,126-130 \mathrm{~cm}$ is slightly enriched in liptinite $(24 \%$; sum of particulate liptinite $\mathrm{A}, \mathrm{B}$, alginite, and amorphous organic matter II). The particulate liptinite $\mathrm{A}$ is derived mainly from marine dinoflagellates. A smaller proportion of the liptinite content in this sample is derived from unicellular algae and biodegraded phyto- and zooplankton. The results of the microscopic investigation of both samples from Hole 549 (Table 2) are consistent with the Rock-Eval pyrolysis data. The abundant populations of recycled vitrinites of very high reflectance yield the same hydrogen index values as would semifusinites (inertinites formed by oxidation of primary terrigenous organic particles), which, however, could be microscopically proven absent.

Table 2 also shows the vitrinite reflectance data of the two samples from Hole 549 already described. The reflectance distribution of vitrinite particles in Sample 549$88-2,126-130 \mathrm{~cm}$ is narrow, and the recycled vitrinite populations $(42 \%)$ are mainly close to $1.5 \% R_{m}$. Very few vitrinite populations of higher maturity $(>1.5 \%$ $R_{m}$ ) were noticed in this sample. In contrast with this, the vitrinite population of Sample 549-45-5, $120-130 \mathrm{~cm}$ is multimodal, and contains mainly vitrinites of recycled nature and higher maturity $\left(>1.5 \% R_{m}\right)$. Spores in this sample are mainly brown, indicating recycling; this is in contrast with the yellow-greenish color of a few primary spores present. The mean vitrinite reflectance values (lowest maximum) for both samples indicate a low maturity of the organic matter.

The temperatures of maximum pyrolysis yield $\left(T_{\max }\right.$; Espitalié et al., 1977) range from 410 to $423^{\circ} \mathrm{C}$ for three samples (Table 1), and correspond to about $0.4 \% R_{m}$, which means that they agree well with the measured vitrinite reflectance values. The extremely high $T_{\max }$ value $\left(544^{\circ} \mathrm{C}\right)$ measured for Sample 550B-15-3, $126-128 \mathrm{~cm}$ is assumed to result from the abundance of recycled vitrinite in this sediment. 
Table 1. Organic carbon contents, total extract yields, and Rock-Eval pyrolysis data for sediment samples from Holes 549 and $550 \mathrm{~B}$.

\begin{tabular}{|c|c|c|c|c|c|c|c|c|}
\hline \multirow[b]{2}{*}{$\begin{array}{c}\text { Sample } \\
\text { (interval in } \mathrm{cm} \text { ) }\end{array}$} & \multirow[b]{2}{*}{$\begin{array}{l}\text { Sub-bottom } \\
\text { depth (m) }\end{array}$} & \multirow[b]{2}{*}{$\begin{array}{l}\text { Chrono- } \\
\text { stratigraphy }\end{array}$} & \multirow[b]{2}{*}{ Lithology } & \multirow[b]{2}{*}{$\mathrm{C}_{\text {org }}(\%)$} & \multirow[b]{2}{*}{$\begin{array}{c}\text { Extract } \\
\text { (mg/g C } \text { org })\end{array}$} & \multicolumn{3}{|c|}{ Rock-Eval pyrolysis } \\
\hline & & & & & & $\begin{array}{c}\text { Hydrogen } \\
\text { index } \\
\text { (mg HC/g } \\
\left.\mathrm{C}_{\text {org }}\right)\end{array}$ & $\begin{array}{c}\text { Oxygen } \\
\text { index } \\
\text { (mg CO} 2 / \mathrm{g} \\
\left.\mathrm{C}_{\text {org }}\right)\end{array}$ & $T_{\max }$ \\
\hline $549-28-1,135-145$ & 446.9 & $\begin{array}{l}\text { middle to upper } \\
\text { Cenomanian }\end{array}$ & $\begin{array}{l}\text { Light } \\
\text { greenish } \\
\text { nannofossil } \\
\text { chalk }\end{array}$ & 0.05 & $(20.0)^{\mathrm{a}}$ & - & - & - \\
\hline $549-45-5,120-130$ & 604.8 & middle Albian & $\begin{array}{l}\text { Gray } \\
\text { calcareous } \\
\text { siltstone }\end{array}$ & 0.51 & 3.5 & 16 & 198 & 423 \\
\hline $549-88-2,126-130$ & 913.3 & $\begin{array}{l}\text { lower } \\
\text { Barremian }\end{array}$ & $\begin{array}{l}\text { Gray sandy } \\
\text { mudstone }\end{array}$ & 0.74 & 7.3 & 69 & 68 & 423 \\
\hline $550 \mathrm{~B}-11-2,120-130$ & 553.8 & $\begin{array}{l}\text { lower } \\
\text { Maestrichtian }\end{array}$ & $\begin{array}{l}\text { Light } \\
\text { greenish } \\
\text { gray chalk }\end{array}$ & 0.04 & $(30.0)^{\mathrm{a}}$ & - & - & - \\
\hline $550 \mathrm{~B}-15-3,126-128$ & 593.3 & $\begin{array}{l}\text { (Coniacian?-) } \\
\text { Santonian }\end{array}$ & $\begin{array}{l}\text { Greenish } \\
\text { gray } \\
\text { calcareous } \\
\text { mudstone }\end{array}$ & 0.19 & 9.5 & 47 & 542 & 544 \\
\hline $550 \mathrm{~B}-21-5,121-126$ & 651.2 & $\begin{array}{l}\text { lower } \\
\text { Cenomanian }\end{array}$ & $\begin{array}{l}\text { Gray } \\
\text { calcareous } \\
\text { mudstone }\end{array}$ & 0.36 & 5.3 & 11 & 406 & 410 \\
\hline
\end{tabular}

${ }^{a}$ Values in parentheses may be erroneous, because of difficulty in determining precisely the very small amounts of total extract.

\section{Extractable Organic Matter}

The amount of extractable organic matter in all samples is small (Table 1), in accordance with the low maturity and the partly recycled nature (which implies oxidation during erosion) of the organic matter. The values for the two extremely organic-carbon-lean samples may be erroneous (set in parentheses in Table 1), owing to the difficulty of determining precisely the very small absolute amounts of total extract. On the other hand, carbonates tend to show a relatively large amount of total extract when normalized to organic carbon, already in the immature stage.

The capillary gas chromatograms of the saturated hydrocarbon fractions of the three samples from Hole 549 are shown in Figures 4A-C. The very organic-carbonlean Cenomanian chalk (Sample 549-28-1, 135-145 cm) contains only traces of hydrocarbons. Short-chain $n$-alkanes predominate, with a maximum at $n$-nonadecane $\left(n-C_{19}\right)$, and in addition there is an unusually large amount of branched or cyclic alkanes in the range of $n-\mathrm{C}_{16}$ to $n$ - $\mathrm{C}_{20}$. The $n$-alkane distribution above $n-\mathrm{C}_{20}$, with no pronounced carbon-number predominance, is characteristic of recycled, refractory organic matter in organiccarbon-lean deep-sea sediments (Rullkötter et al., 1980). The $n$-alkane predominance in the range of low molecular weight would indicate some algal contribution, although contamination during sample handling should be considered a very likely explanation in view of the low organic carbon content.

Sample 549-45-5, 120-130 cm (Albian) has a bimodal $n$-alkane envelope (Fig. 4B). Higher-plant waxes apparently have contributed to the long-chain portion, in which there is a maximum at $n-\mathrm{C}_{29}$ and a marked predominance of odd carbon numbers (Eglinton and Hamilton, 1963). The smooth distribution in the range of lower molecular weight may be due to a contribution from more mature organic matter reworked from previously more deeply buried rocks; this would be consistent with the microscopy results. The lower Barremian sandy mudstone (Sample 549-88-2, 126-130 cm; Fig. 4C) shows a predominance of long-chain $n$-alkanes $\left(\mathrm{C}_{23}-\mathrm{C}_{29}\right)$. The strong predominance of odd carbon numbers indicates an origin in terrestrial higher-plant waxes (Eglinton and Hamilton, 1963) and a low maturity of the organic matter. High concentrations of polycylic saturated and unsaturated hydrocarbons (Table 3; see Fig. 5 for compound structures) show that the conditions for preservation of organic matter were more favorable than in the other two samples from Hole 549 (cf. Rullkötter et al., 1982). Hopanoid hydrocarbons of microbial origin (Ourisson et al., 1979) have the highest abundance, and the presence of olefins and $17 \beta(\mathrm{H})$-hopanes again indicates the low maturity of the organic matter. Steroid hydrocarbons are present, but in lower concentrations than the hopanoids. Diasterenes dominate, followed by minor amounts of $5 \alpha(\mathrm{H})$-steranes and traces of regular sterenes. In each case, the $\mathrm{C}_{29}$ homologues have the highest relative abundance in the $\mathrm{C}_{27}$ to $\mathrm{C}_{29}$ series, indicating a major terrigenous origin of the steroids (Huang and Meinschein, 1979).

Figure 6 shows the saturated-hydrocarbon chromatograms of the three samples from Hole 550B. The very organic-carbon-lean Maestrichtian chalk (Sample 550B$11-2,120-130 \mathrm{~cm}$ ) is dominated by an unresolved hump (Fig. 6A). In view of the extremely low organic carbon content, it is questionable whether the chromatogram displays the indigenous hydrocarbon composition; a major contribution from organic contaminants cannot be ruled out. The other two samples from Hole 550B have saturated-hydrocarbon distributions very similar to each other (Figs. 6B, C). The main difference is a higher abun- 

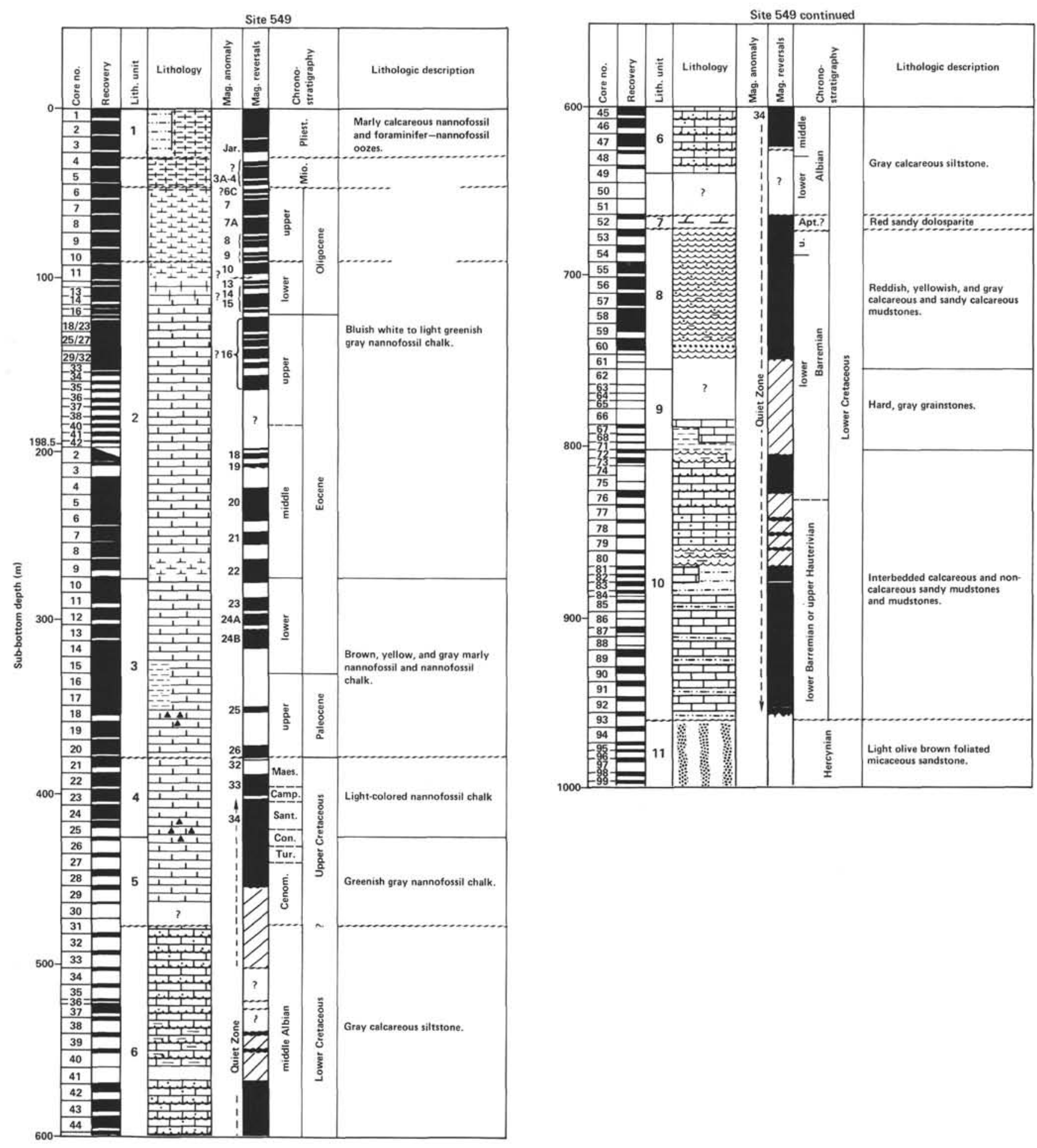

Figure 2. Lithologic columns of DSDP Sites 549 and 550 (from de Graciansky et al., in press).

dance of $n$-alkanes in the $\mathrm{C}_{21}$ to $\mathrm{C}_{25}$ molecular range in the lower Cenomanian calcareous mudstone (Sample 550B-21-5, 121-126 cm). These may be microbially degraded higher-plant wax alkanes, but the smooth distribution suggests that contamination by a refinery product (e.g., diesel fuel) cannot be excluded. Cyclic and branched hydrocarbons are of low abundance in both the Cenomanian and the (Conacian?-) Santonian sam- ple, indicating depositional environments not very favorable for preservation of organic matter.

\section{CONCLUSIONS}

Rock-Eval pyrolysis and kerogen microscopy reveal a terrigenous type III kerogen for the lower Barremian sample from Hole 549, with a tendency to more oxidized organic matter of the same origin in the middle Albian to 


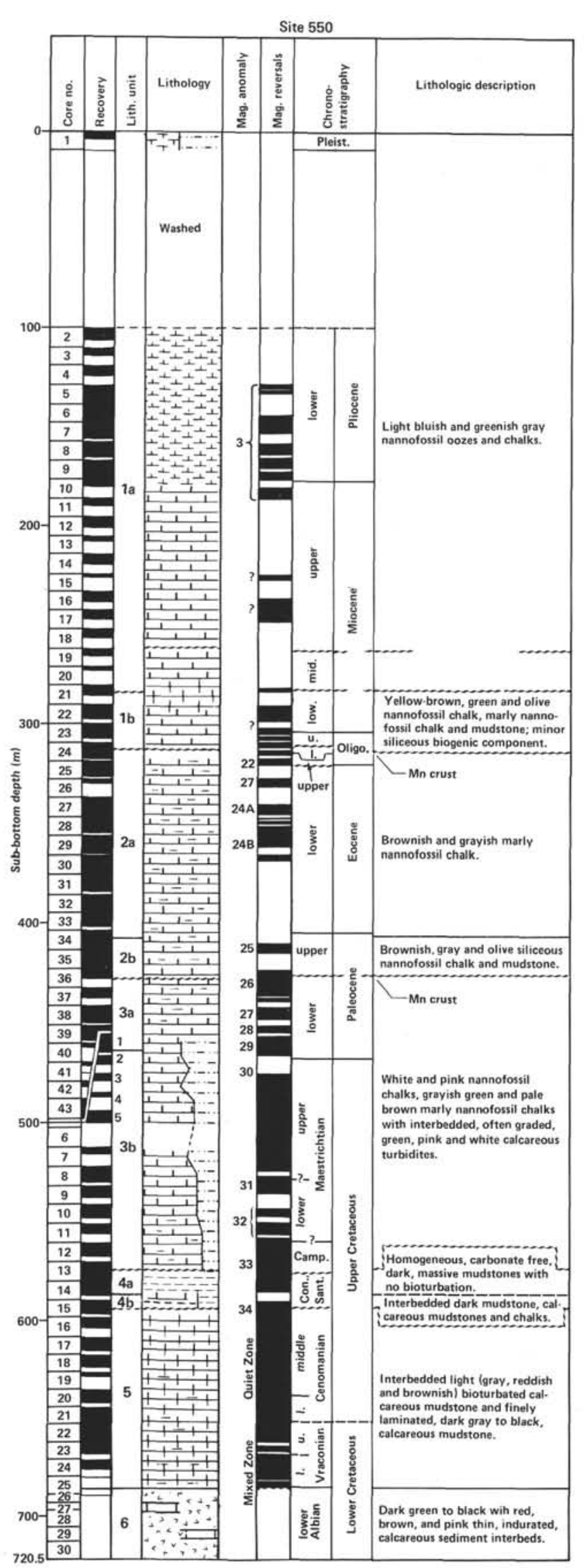

Figure 2. (Continued).

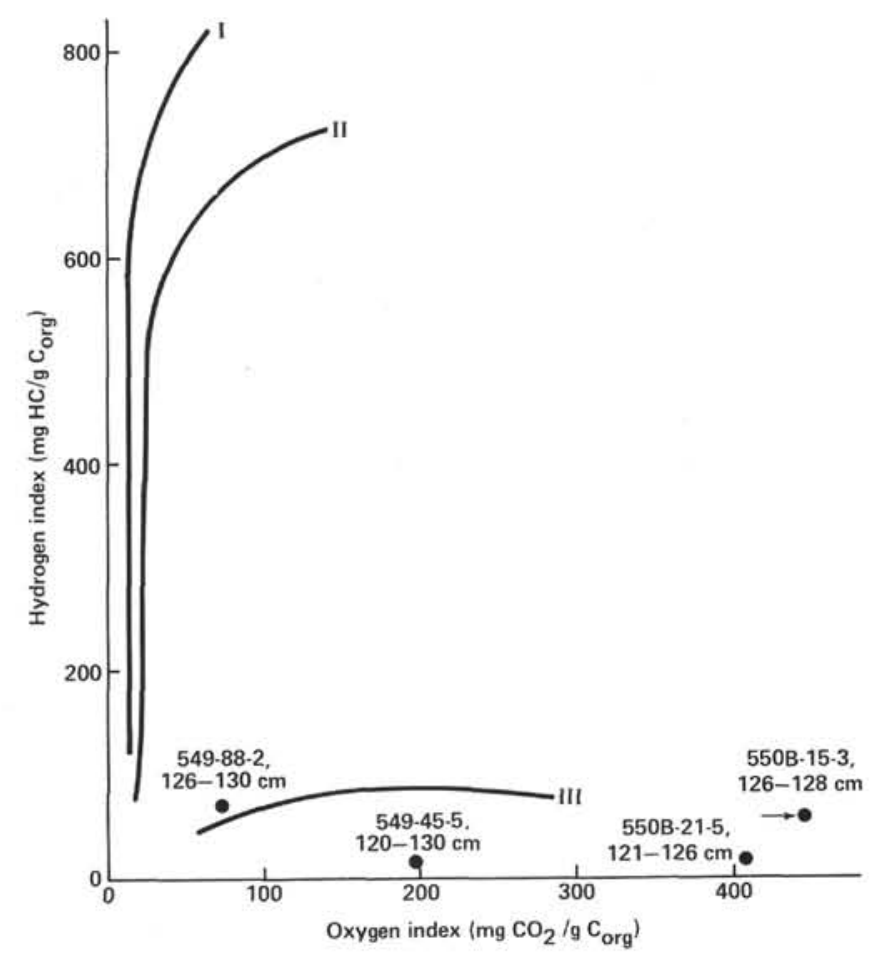

Figure 3. Results of Rock-Eval pyrolysis displayed on a hydrogen index-versus-oxygen index diagram (Espitalié et al., 1977) for four sediment samples from Sites 549 and 550 .

middle/upper Cenomanian samples from Hole 549, as well as the lower Cenomanian to lower Maestrichtian samples from Hole 550B. The amount of total organic carbon increases with stratigraphic age, but it is generally low. Only two sediment samples exceed values of $0.5 \% \mathrm{C}_{\text {org. }}$.

Both microscopically investigated samples show a very strong influx of terrestrial organic matter, which predominates in the lower Barremian claystone $(85 \%)$ and even in the mid-Albian mudstone $(99 \%)$. In the Barremian sediment, a slight enrichment with marine phytoplankton becomes evident: this cannot be directly traced in the saturated-hydrocarbon composition, but the presence of abundant polycyclic hydrocarbons indicates generally more favorable conditions for the preservation of organic matter. Overall, deposition of organic matter in the Cretaceous at the Goban Spur occurred in probably deep, well-oxygenated water, which allowed mainly the terrigenous organic matter, together with some recycled material from older rocks, to survive and accumulate in the sediments.

The temperatures of maximum pyrolysis yield, the vitrinite reflectance values, and the predominance of oddnumbered $n$-alkanes around $\mathrm{C}_{29}$, all indicate a low maturation level of the organic matter in the sediments, corresponding to vitrinite reflectance values up to about $0.4 \%$ $R_{m}$, over the interval 446.9 to $913.3 \mathrm{~m}$.

\section{ACKNOWLEDGMENTS}

We thank Dr. J. Gormly for Rock-Eval pyrolysis and Dr. M. Radke for extraction/liquid chromatography. Technical assistance by M. De- 
Table 2. Organic petrography data for sediment samples from Holes 549 and 550B.

\begin{tabular}{|c|c|c|c|c|c|c|c|c|c|c|c|c|}
\hline \multirow{3}{*}{$\begin{array}{c}\text { Sample } \\
\text { (interval in } \mathrm{cm} \text { ) }\end{array}$} & \multirow{3}{*}{$\begin{array}{l}\text { Sub-bottom } \\
\text { depth (m) }\end{array}$} & \multirow{3}{*}{$\begin{array}{l}\text { Chrono- } \\
\text { stratigraphy }\end{array}$} & \multicolumn{8}{|c|}{ Maceral analysis (vol. \%) } & \multirow{2}{*}{\multicolumn{2}{|c|}{$\begin{array}{c}\text { Vitrinite } \\
\text { reflectance }\end{array}$}} \\
\hline & & & & inite & & & & & & & & \\
\hline & & & Prim. & Recycl. & Amp. III & Inert. & Part. B & Part. A & Alg. & Amp. II & $R_{m}$ & Std. dev. \\
\hline $549-45-5,120-130$ & 604.8 & middle Albian & 11 & 59 & 1 & 23 & 5 & 1 & - & - & 0.36 & 0.03 \\
\hline $549-88-2,126-130$ & 913.3 & lower Barremian & 22 & 42 & 2 & 10 & 9 & 11 & 1 & 3 & 0.36 & 0.05 \\
\hline
\end{tabular}

Note: Prim. = primary (vitrinite); Recycl, = recycled (vitrinite); Amp. III = amorphous organic matter III = biodegraded humic matter; Inert. = inertinite; Part. B = particulate liptinite B, i.e., sporinite, cutinite, resinite, and suberinite = terrestrial liptinites; Part. $\mathrm{A}=$ particulate liptinite $\mathrm{A}=$ phyto- and zooclasts (includes dinoflagellates; cf. Van Gijzel, 1980) = aquatic liptinites other than alginite; Alg. = alginite; Amp. II = amorphous organic matter II = biodegraded liptinites; $R_{m}=$ mean vitrinite reflectance of primary particles (lowest reflecting population); Std. dev. $=$ standard deviation.

richs, U. Disko, B. Kammer, J. Schnitzler, K. Sellinghoff, and B. Winden is gratefully acknowledged. We are indebted to Dr. C. Cornford (Britoil, Glasgow, Scotland) for a careful review and helpful comments. This work was financially supported by the Deutsche Forschungsgemeinschaft (DFG, Bonn), grant No. We 346/25-6.

\section{REFERENCES}

de Graciansky, P. C., Poag, C. W., Cunningham, R., Loubere, P., Masson, D. G., et al., in press. The Goban Spur transect-geologic evolution of a sediment-starved passive continental margin. Bull. Geol. Soc. Am.

Eglinton, G., and Hamilton, R. J., 1963. The distribution of alkanes. In Swain, T. (Ed.), Chemical Plant Taxonomy: London (Academic Press), pp. 187-217.

Espitalié, J., Laporte, J. L., Madec, M., Marquis, F., Leplat, P., et al., 1977. Méthode rapide de caractérisation des roches-mères, de leur potential pétrolier et de leur degré d'évolution. $R$. Inst. Fr. Pet., 32:23-42.

Huang, W. Y., and Meinschein, W. G., 1979. Sterols as ecological indicators. Geochim. Cosmochim Acta, 43:739-745.

Mukhopadhyay, P. K., Gormly, J. R., and Welte, D. H., in press. Classification of kerogens based on hydrocarbon potential and maturation. To be submitted to Erdöl, Kohle, Erdgas Petrochem.

Mukhopadhyay, P. K., Rullkötter, J., and Welte, D. H., 1983. Facies and diagenesis of organic matter in sediments from the Brazil Basin and the Rio Grande Rise, Deep Sea Drilling Project Leg 72. In Barker, P. F., Carlson, R. L., Johnson, D. A., et al., Init. Repts. DSDP, 72: Washington (U.S. Govt. Printing Office), 821-828.

Ourisson, G., Albrecht, P., and Rohmer, M., 1979. The hopanoids paleochemistry and biochemistry of a group of natural products. Pure Appl. Chem., 51:709-729.

Rullkötter, J., Cornford, C., and Welte, D. H., 1982. Petrography and geochemistry of organic matter in northwest African continental margin sediments: quantity, provenance, depositional environment, and temperature history. In von Rad, U., Hinz, K., Sarnthein, M., and Seibold, E. (Eds.), Geology of the Northwest African Continental Margin: Heidelberg (Springer Verlag), pp. 686-703.

Rullkötter, J., Flekken, P., and Welte, D. H., 1980. Organic petrography and extractable hydrocarbons of sediments from the northern Philippine Sea, Deep Sea Project Leg 58. In Klein, G. de V., Kobayashi, K., et al., Init. Repts. DSDP, 58: Washington (U.S. Govt. Printing Office), 755-762.

Rullkötter, J., Mukhopadhyay, P. K., Schaefer, R. G., and Welte, D. $\mathrm{H}$., in press. Geochemistry and petrography of organic matter in sediments from DSDP Sites 545 and 547, Mazagan Escarpment. In Hinz, K., Winterer, E. L., et al., Init. Repts. DSDP, 79: Washington (U.S. Govt. Printing Office).

Rullkötter, J., Mukhopadhyay, P. K., and Welte, D. H., 1984. Geochemistry and petrography of organic matter in sediment from Hole 530A, Angola Basin, and 532, Walvis Ridge, Deep Sea Drilling Project. In Hay, W. W., Sibuet, J.-C., et al., Init. Repts. DSDP, 75: Washington (U.S. Govt. Printing Office), 1069-1087.

Rullkötter, J., von der Dick, H., and Welte, D. H., 1981. Organic petrography and extractable hydrocarbons of sediments from the eastern North Pacific Ocean, Deep Sea Drilling Project Leg 63. In Yeats, R. S., Haq, B. U., et al., Init. Repts. DSDP, 63: Washington (U.S. Govt. Printing Office), 819-836.

Teichmüller, M., and Ottenjann, K., 1977. Art und Diagenese von Liptiniten und lipoiden Stoffen in einem Erdölmuttergestein aufgrund fluoreszenzmikroskopischer Untersuchungen. Erdöl, Kohle, Erdgas Petrochem., 30:387-398.

Van Gijzel, P., 1980. Characterisation and identification of kerogen and bitumen and determination of thermal maturation by means of qualitative and quantitative microscopical techniques. How to Assess Maturation and Paleotemperature, Short Course: Denver (Soc. Econ. Paleontol. Mineral.), pp. 159-214.

Date of Initial Receipt: June 7, 1983

Date of Acceptance: July 26, 1983 

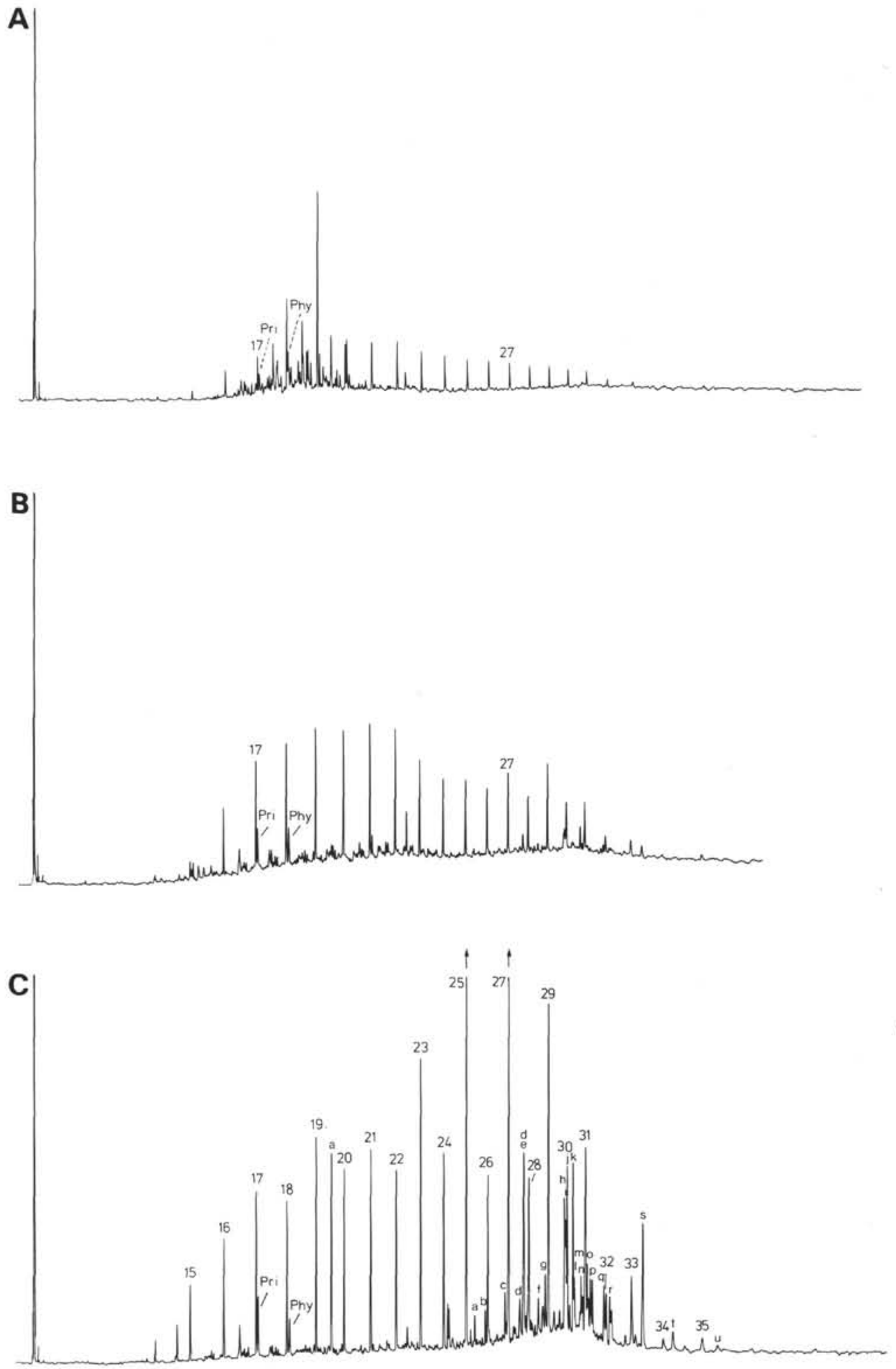

Figure 4. Capillary gas chromatograms of the saturated-hydrocarbon fractions of three rock samples from Hole 549. A. Sample 549-28-1, $135-145 \mathrm{~cm}$. B. Sample 549-45-5, 120-130 cm. C. Sample 549-88-2, $126-130 \mathrm{~cm}$. Analytical conditions: glass capillary column, $23 \mathrm{~m}$ length, $0.3 \mathrm{~mm}$ i.d., coated with SE 54 silicone elastomer, temperature programmed from $80^{\circ} \mathrm{C}$ (hold for $2 \mathrm{~min}$.) with a $3 \% \mathrm{~min}$. heating rate up to $254^{\circ} \mathrm{C}$. Helium is the carrier gas. See Table 3 for peak identifications on chromatogram C. 
Table 3. Cyclic compounds identified by gas chromatography/mass spectrometry in the nonaromatic hydrocarbon fraction of Sample $549-88-2,126-130 \mathrm{~cm}$ (compounds identified in Fig. 4C chromatogram.

\begin{tabular}{|c|c|c|}
\hline $\begin{array}{l}\text { Peak } \\
\text { on } \\
\text { Fig. } 4 \mathrm{C}\end{array}$ & Compound & Structure (see Fig. 5) \\
\hline a & phthalate contaminants & \\
\hline b & diacholest-13(17)-ene & $\mathrm{I}, \mathrm{R}=\mathrm{H}$ \\
\hline c & 24-methyldiacholest-13(17)-ene & $1, \mathrm{R}=\mathrm{CH}_{3}$ \\
\hline d & 24-ethyldiacholest-13(17)-ene & $\mathrm{I}, \mathrm{R}=\mathrm{C}_{2} \mathrm{H}_{5}$ \\
\hline e & 22,29,30-trisnorhop-17(21)-ene & $\mathrm{II}, \mathrm{R}=\mathrm{H}$ \\
\hline $\mathrm{f}$ & $22,29,30$-trisnor-17 $\alpha(\mathrm{H})$-hopane & III, $\mathrm{R}=\mathrm{H}$ \\
\hline $\mathrm{g}$ & $22,29,30$-trisnor-17 $\beta(\mathrm{H})$-hopane & IV, $\mathrm{R}=\mathrm{H}$ \\
\hline $\mathrm{h}$ & 30-norneohop-13(18)-ene & $\mathrm{V}, \mathrm{R}=\mathrm{H}$ \\
\hline i & 30-norhop-17(21)-ene & II, $\mathrm{R}=\mathrm{C}_{2} \mathrm{H}_{5}$ \\
\hline & (+ 30-nor-17 $\alpha(\mathrm{H})$-hopane?) & III, $\mathrm{R}=\mathrm{C}_{2} \mathrm{H}_{5}$ \\
\hline $\mathrm{j}$ & $\begin{array}{l}\text { 24-ethyl-5 } \alpha(\mathrm{H}) \text {-cholestane } \\
\text { (coeluting with } n-\mathrm{C}_{30} \text { ) }\end{array}$ & VI \\
\hline $\mathrm{k}$ & hop-17(21)-ene & II, $\mathrm{R}=\mathrm{CH}\left(\mathrm{CH}_{3}\right)_{2}$ \\
\hline 1 & 30-normoretane & VII \\
\hline $\mathrm{m}$ & $17 \alpha(\mathrm{H})$-hopane & III, $\mathrm{R}=\mathrm{CH}\left(\mathrm{CH}_{3}\right)_{2}$ \\
\hline $\mathrm{n}$ & neohop-13(18)-ene & $\mathrm{V}, \mathrm{R}=\mathrm{CH}_{3}$ \\
\hline o & 30-nor-17ß $(\mathrm{H})$-hopane & IV, $\mathrm{R}=\mathrm{C}_{2} \mathrm{H}_{5}$ \\
\hline $\mathrm{p}$ & homohop-17(21)-ene ( 2 diastereomers) & II, $\mathrm{R}=\mathrm{CH}\left(\mathrm{CH}_{3}\right) \mathrm{C}_{2} \mathrm{H}_{5}$ \\
\hline $\mathrm{q}$ & $17 \alpha(\mathrm{H})$-homohopane & III, $\mathrm{R}=\mathrm{CH}\left(\mathrm{CH}_{3}\right) \mathrm{C}_{2} \mathrm{H}_{5}$ \\
\hline $\mathrm{r}$ & $17 \beta(\mathrm{H})$-hopane & IV, $\mathrm{R}=\mathrm{CH}\left(\mathrm{CH}_{3}\right)_{2}$ \\
\hline $\mathrm{s}$ & $17 \beta(\mathrm{H})$-homohopane & IV, $\mathrm{R}=\mathrm{CH}\left(\mathrm{CH}_{3}\right) \mathrm{C}_{2} \mathrm{H}_{5}$ \\
\hline $\mathrm{t}$ & $17 \beta$ (H)-bishomohopane & IV, $\mathrm{R}=\mathrm{CH}\left(\mathrm{CH}_{3}\right) \mathrm{C}_{3} \mathrm{H}_{7}$ \\
\hline $\mathbf{u}$ & $17 \beta(\mathrm{H})$-trishomohopane & IV, $\mathrm{R}=\mathrm{CH}\left(\mathrm{CH}_{3}\right) \mathrm{C}_{4} \mathrm{H}_{9}$ \\
\hline
\end{tabular}<smiles>[R]C(C)C(C)CCC(C)C1=C2CCC3C4CCCCC4(C)CCC3C2(C)CC1</smiles><smiles>CCC1CCC23C(CCC4C5CCC6C(C)(C)CCCC6(C)C5CCC42C)CCC13</smiles>

v<smiles>[R]C(C)C1CCC2=C3CC[C@@H]4C(C)(C)CCCC4(C)[C@@]3(C)CC[C@@]21C</smiles><smiles>CCC1CCC23CCC4C(CCC4C(C)(C)C)CCC12CCC3C(C)(C)C</smiles>

Figure 5. Chemical structures.
11<smiles>[R]C1=C2CC[C@@]3(C)C(C)CCC3[C@@]2(C)CCC2C(C)(C)CCC[C@]12C</smiles>

IV

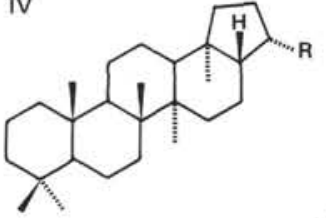

VI<smiles>CCC(CCC(C)C1CCC2C3CCC4CCCC[C@]4(C)C3CC[C@]12C)C(C)C</smiles> 

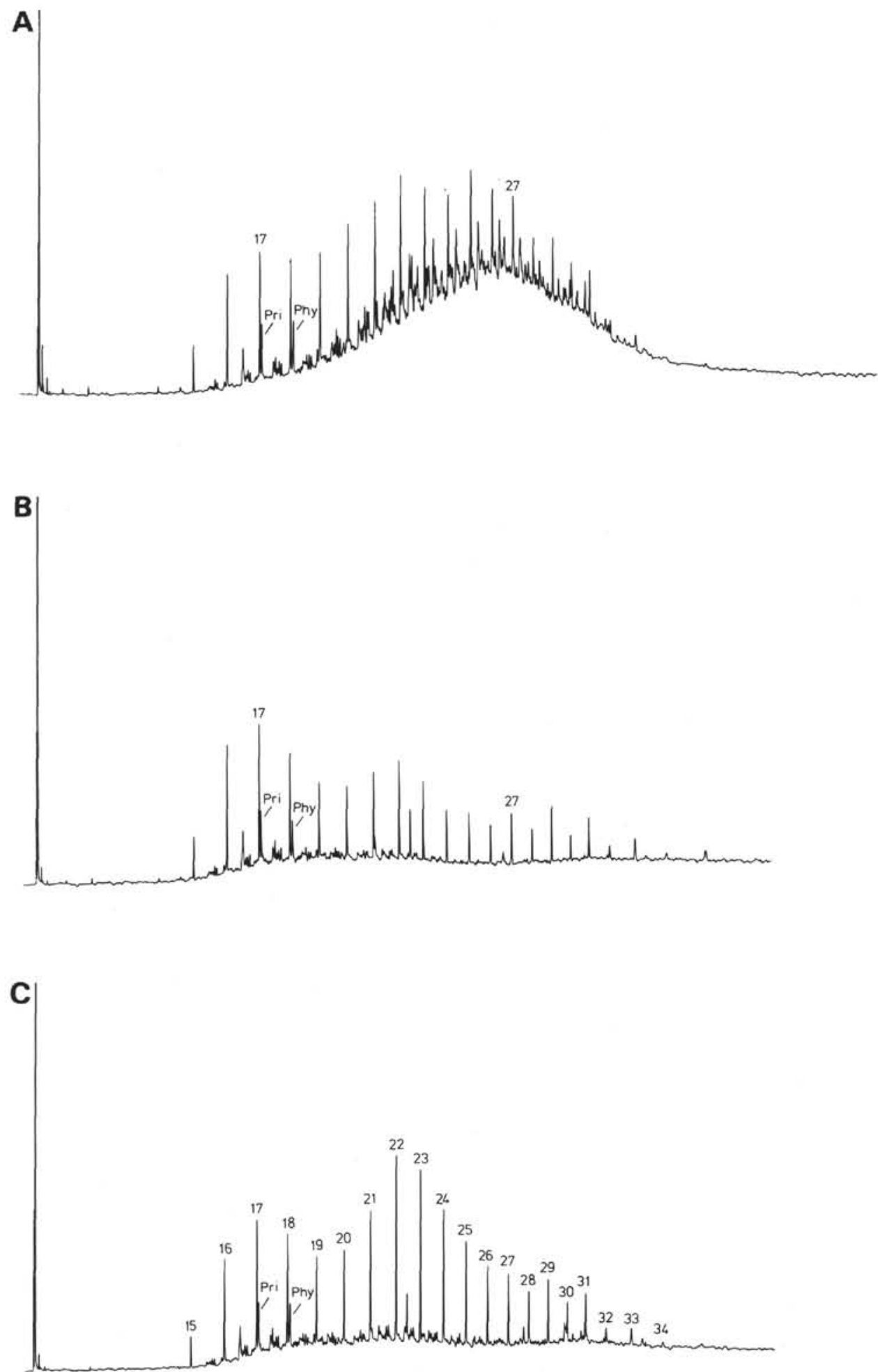

Figure 6. Capillary gas chromatograms of the saturated-hydrocarbon fractions of three rock samples from Hole 550B. A. Sample 550B-11-2, 120-130 cm. B. Sample 550B-15-3, 126-128 cm. C. Sample $550 \mathrm{~B}-21-5,121-126 \mathrm{~cm}$. For analytical details see Figure 4. 